\title{
Absolute Structures of Stemona-Lactam S and Tuberostemospiroline, Alkaloids from Stemona tuberosa
}

\author{
Haruhiko Fukaya, ${ }^{a}$ Yukio Hitotsuyanagi, ${ }^{a}$ Yutaka Aoyagi, ${ }^{b}$ Zhu Shu, ${ }^{c}$ Katsuko Komatsu, ${ }^{c}$ and \\ Koichi Takeya*,a \\ ${ }^{a}$ School of Pharmacy, Tokyo University of Pharmacy and Life Sciences; 1432-1 Horinouchi, Hachioji, Tokyo \\ 192-0392, Japan: ${ }^{b}$ Department of Pharmacy, Kinjo Gakuin University; 2-17723 Omori, Moriyama-ku, Nagoya 463- \\ 8521, Japan: and ${ }^{c}$ Division of Pharmacognosy, Department of Medicinal Resources, Institute of Natural Medicine, \\ University of Toyama; 2630 Sugitani, Toyama 930-0194, Japan. \\ Received June 9, 2013; accepted July 31, 2013
}

A new alkaloid, stemona-lactam S, and a known alkaloid, tuberostemospiroline, were isolated from the roots of Stemona tuberosa Lour. (Stemonaceae). Their structures and absolute stereochemistry were established by X-ray crystallography and vibrational circular dichroism.

Key words stemona-lactam S; tuberostemospiroline; Stemona tuberosa; absolute configuration; X-ray crystallography; vibrational circular dichroism

The roots of Stemona japonica (Blume) MiQ., S. tuberosa Lour., and S. sessilifolia (MiQ.) MiQ. are used as an antitussive and an insecticide in traditional medicine in China and Japan, and the alkaloidal components are responsible for such biological activities. ${ }^{1-3)}$ In the course of our work ${ }^{4,5)}$ on the alkaloids from $S$. tuberosa, a new alkaloid, stemona-lactam $\mathrm{S}$ (1), and a known alkaloid, tuberostemospiroline (2), ${ }^{6}$ were isolated from this plant source and their absolute structures were determined by X-ray crystallography and vibrational circular dichroism (VCD) (Fig. 1).

\section{Results and Discussion}

Stemona-lactam S (1) was obtained as colorless prisms by repeated chromatography of the alkaloidal fraction from the roots of $S$. tuberosa. The molecular formula was established to be $\mathrm{C}_{14} \mathrm{H}_{19} \mathrm{NO}_{4}$ based on the quasi-molecular ion peak at $\mathrm{m} / \mathrm{z}$ $288.1219[\mathrm{M}+\mathrm{Na}]^{+}$by high-resolution electrospray-ionization mass spectrum (HR-ESI-MS), indicating compound $\mathbf{1}$ to be an alkaloid. Recrystallization of $\mathbf{1}$ was carried out by slow evaporation of $\mathrm{MeOH}-\mathrm{H}_{2} \mathrm{O}$ at room temperature. A crystal of suitable size $(0.29 \times 0.24 \times 0.12 \mathrm{~mm})$ was obtained for X-ray crystallographic analysis and the diffraction data were collected at $90 \mathrm{~K}$. A total of 3250 reflections were collected at the scan width of $0.5^{\circ}$ and the exposure time of $3 \mathrm{~s} /$ frame, within the $\theta$ range of 2.05 to $25.02^{\circ}$ with index ranges of $-6 \leq h \leq 9,-10 \leq k \leq 10$, and $-12 \leq l \leq 11$. The number of independent reflections was $2173\left(R_{\text {int }}=0.012\right)$ and that of observed reflections with $I>2 \sigma(I)$ was 2131 . The crystal belonged to the monoclinic system and the space group was $P 2_{1}$ with cell dimensions of $a=7.6013(8) \AA, b=8.9374(10) \AA, c=10.3357(12) \AA$, $\beta=106.216(4)^{\circ}$ and $V=674.23(13) \AA^{3}, D_{\text {calc }}=1.307 \mathrm{~g} / \mathrm{cm}^{3}, Z=2$, and $F(000)=284$. Integration and reduction of all data were carried out with the Bruker Suite software package. ${ }^{7)}$ Numerical absorption correction was applied with SADABS. ${ }^{8)}$ The structures were solved by direct methods using SHELXS-979) and refined by full-matrix least-squares calculations with SHELXL-97. ${ }^{10)}$ Non-hydrogen atoms were refined anisotropically and all hydrogen atoms except those attached to the nitrogen atom were placed in geometrically calculated positions

The authors declare no conflict of interest.
(C-H $0.98 \AA)$ and treated as riding on their parent atoms. The final $R$ indices were $R_{1}=0.0250, w R_{2}=0.0649$ for reflections with $I>2 \sigma(I)$ and $R_{1}=0.0255, w R_{2}=0.0655$ for all data. The Flack absolute structure parameter ${ }^{11)}$ was $0.8(7)$. The S (goodness-of-fit) value was 1.03 and the largest residual peak and hole in the final difference map were $0.13 \mathrm{e} / \AA^{3}$ and $-0.14 \mathrm{e} /$ $\AA^{3}$, respectively. The ORTEP representation of $\mathbf{1}$ is shown in Fig. 2.

The absolute configuration of compound $\mathbf{1}$ was established by VCD spectroscopy, which is a useful method for the determination of the absolute configuration in chiral molecules and has been applied to several natural products. ${ }^{12-14)}$ This method is based on the comparison of experimental IR and VCD spectra with those obtained by density functional theory (DFT) calculations. ${ }^{15)}$ Conformational analysis of 1 with $8 R, 9 S, 10 S$, and $11 R$ configuration by the Monte Carlo conformational search with MMFF94S force field gave five conformers within $5 \mathrm{kcal} / \mathrm{mol}$ from the global minimum energy conformation. In order to estimate their conformational population, single-point energy calculations were performed for those conformers at the DFT/B3LYP/6-31G(d,p) level. The results indicated that among the five conformers, the three lowest energy conformers, $\mathbf{1 a}, \mathbf{1 b}$, and $\mathbf{1 c}$, were in the relative energy range of $0.6 \mathrm{kcal} / \mathrm{mol}$ and were estimated to contribute to $94.8 \%$ of the total population. The geometries of the three conformers were further optimized at the B3PW91/DGDZVP2 level and the calculated relative energies and the Boltzmann populations are summarized in Table 1. The three optimized conformers of 1 possessed essentially the same conformation except for the

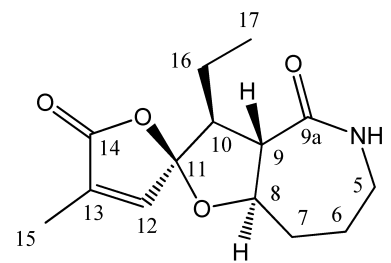

stemona-lactam S (1)

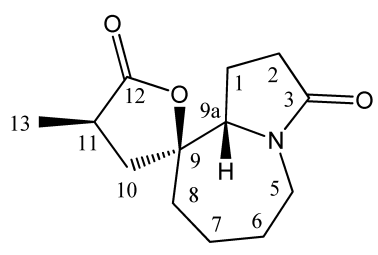

tuberostemospiroline (2)
Fig. 1. Structures of Stemona-Lactam S (1) and Tuberostemospiroline (2) 


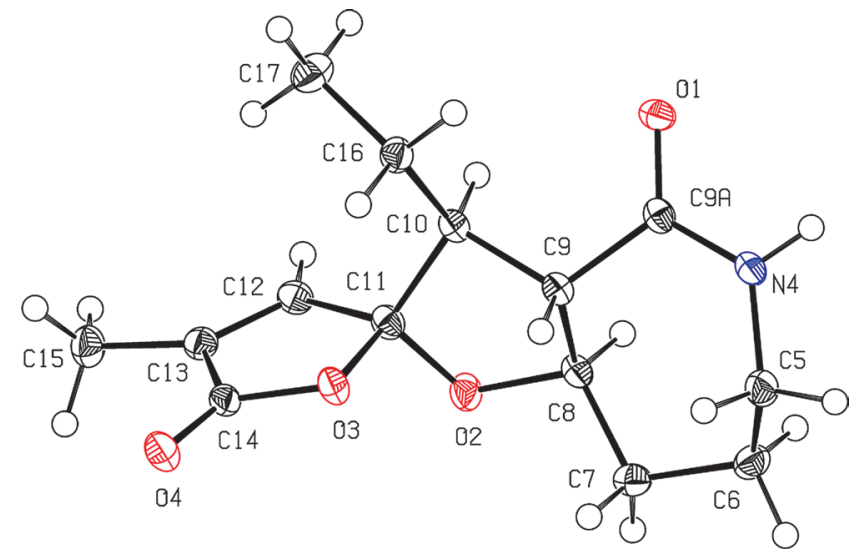

Fig. 2. ORTEP Drawing of the Crystal Structure of Stemona-Lactam S (1)

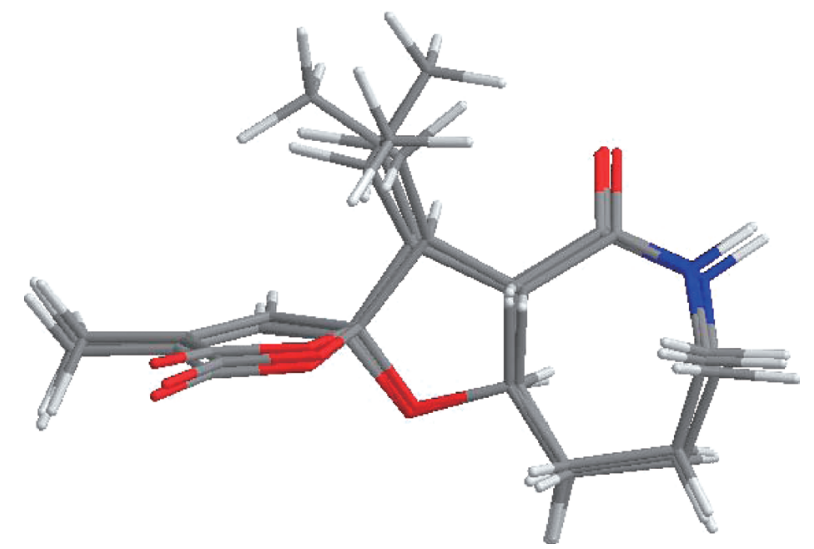

Fig. 3. Superposition of the Structures of Conformers 1a, 1b, and 1c Their geometries were optimized at the B3PW91/DGDZVP2 level.

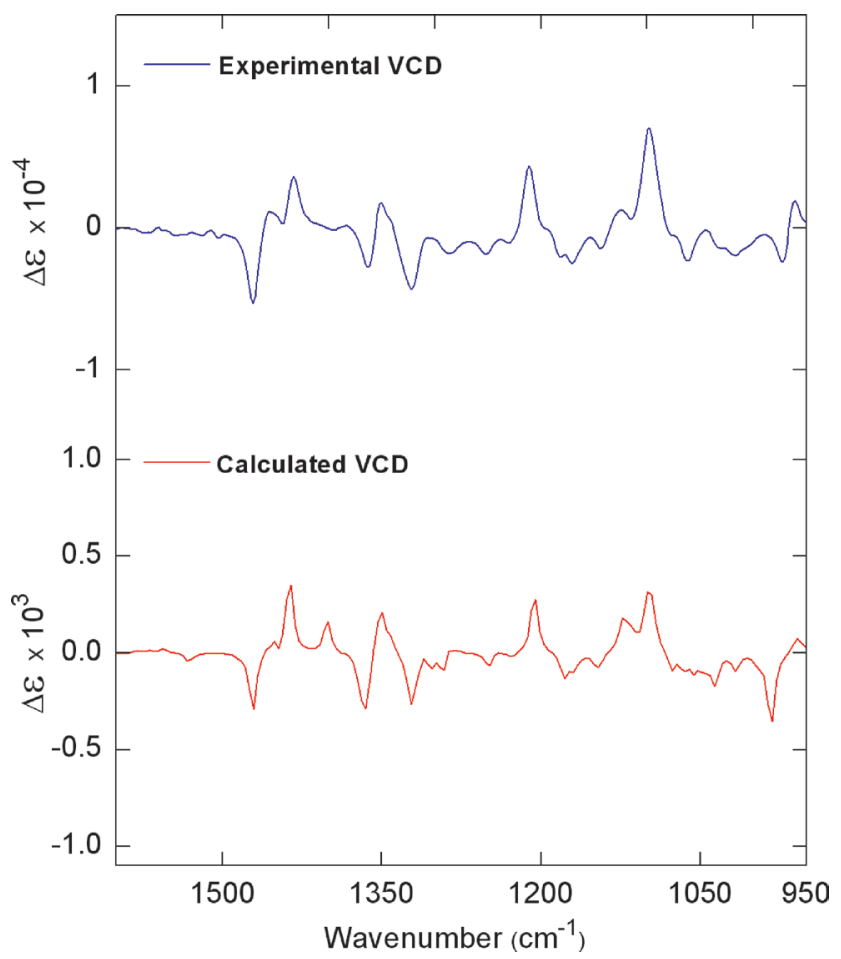

Fig. 4. Comparison of Experimental VCD Spectrum (Top) and Population-Weighted Calculated VCD Spectrum (Bottom) of $(8 R, 9 S, 10 S, 11 R)-1$

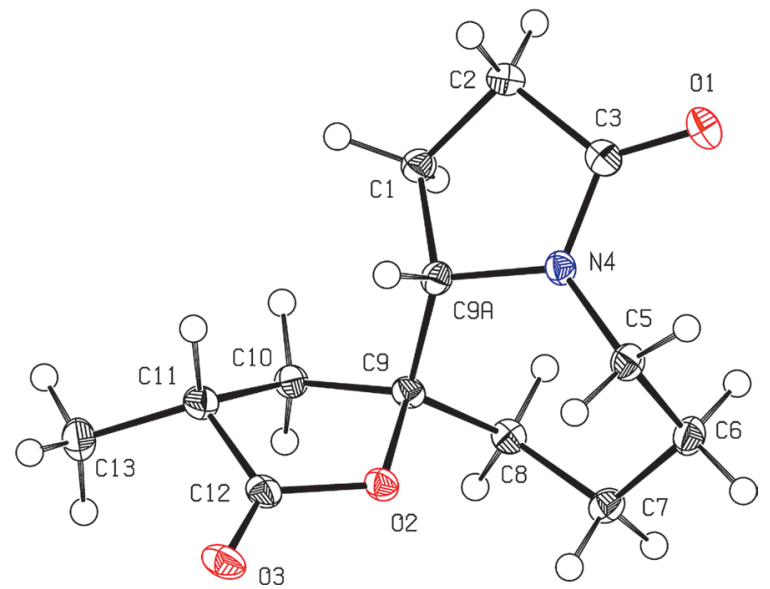

Fig. 5. ORTEP Drawing of the Crystal Structure of Tuberostemospiroline (2)

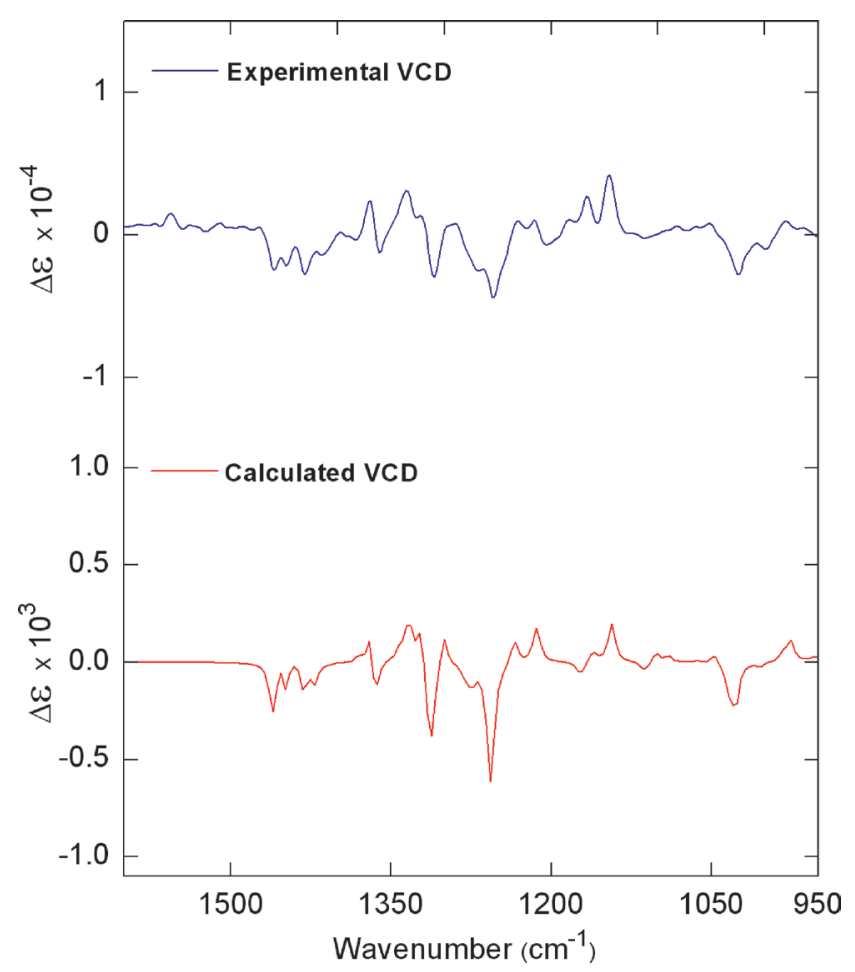

Fig. 6. Comparison of Experimental VCD Spectrum of 2 (Top) with Calculated VCD Spectrum (Bottom) of $(9 S, 9 \mathrm{a} S, 11 R)-\mathbf{2}$ with $\mathrm{CHCl}_{3}$

side chain torsions (Fig. 3). The IR and VCD frequencies and intensities for each optimized conformer were calculated and the theoretical VCD spectrum of $\mathbf{1}$ was obtained by combining the spectra of the conformers weighted according to the Boltzmann population (Fig. 4). As can be seen from Fig. 4, the calculated VCD spectrum of $(8 R, 9 S, 10 S, 11 R)-\mathbf{1}$ was in good agreement with the experimental VCD spectrum of natural 1. Thus, the absolute structure of stemona-lactam $S$ (1) was determined to be that shown in Fig. 1 with $8 R, 9 S, 10 S$, and $11 R$ configuration.

Tuberostemospiroline (2) was previously isolated from this species by Hua et al. ${ }^{6)}$ Although its relative structure was determined by interpretation of NMR data, the structure depicted in the literature was incorrect.6) We confirmed its relative structure by X-ray crystallography and established its 
absolute structure by VCD spectroscopy. A crystal of optimal size $(0.30 \times 0.21 \times 0.17 \mathrm{~mm})$, which was obtained by recrystallization from $\mathrm{MeOH}-\mathrm{H}_{2} \mathrm{O}$ by slow evaporation at room temperature, was submitted for X-ray crystallographic analysis. The experimental X-ray data consisting of 5643 reflections were collected at the scan width of $0.5^{\circ}$ and the exposure time of $3 \mathrm{~s} /$ frame in the range of 2.5 to $25.0^{\circ}$ with the index ranges of $-10 \leq h \leq 8,-11 \leq k \leq 11$, and $-16 \leq l \leq 15$. The number of independent reflections was $2069\left(R_{\text {int }}=0.019\right)$ and that of observed reflections with $I>2 \sigma(I)$ was 2018 . The crystal belongs to the orthorhombic system and the space group was $P 22_{1} 2_{1} 2_{1}$ with cell dimensions of $a=8.4665(9) \AA, \quad b=10.0481(11) \AA$, $c=13.7603(15) \AA$, and $V=1170.6(2) \AA^{3}, D_{\text {calc }}=1.346 \mathrm{~g} / \mathrm{cm}^{3}, Z=4$, and $F(000)=512$. Non-hydrogen atoms were refined anisotropically and all hydrogen atoms were placed in geometrically calculated positions $(\mathrm{C}-\mathrm{H} 0.98 \AA)$ and treated as riding on their parent atoms. The final $R$ indices were $R_{1}=0.0291$, $w R_{2}=0.0729$ for reflections with $I>2 \sigma(I)$ and $R_{1}=0.0301$, $w R_{2}=0.0738$ for all data. The Flack absolute structure parameter was $-0.1(10)$. The $\mathrm{S}$ value was 1.06 and the largest residual peak and hole in the final difference map were $0.17 \mathrm{e} /$ $\AA^{3}$ and $-0.23 \mathrm{e} / \AA^{3}$, respectively. The ORTEP representation of $\mathbf{2}$ is shown in Fig. 5. Monte Carlo conformational search of 2 with $9 S, 9 \mathrm{a} S$, and $11 R$ configuration gave four conformers and single-point energy calculations were carried out for those four conformers at the B3LYP/6-31G(d,p) level. The results showed that the energy difference between the lowest energy conformer and the second lowest energy conformer was $3.34 \mathrm{kcal} / \mathrm{mol}$, and that between the lowest energy conformer and the third lowest energy conformer was $11.84 \mathrm{kcal} / \mathrm{mol}$. Thus, the conformational distribution of this lowest energy conformer was estimated to be more than $99.6 \%$ in $\mathbf{2}$. The theoretical VCD spectrum of $\mathbf{2}$ was calculated using this lowest energy conformer structure as a $1: 1$ complex with a $\mathrm{CHCl}_{3}$ molecule at the B3PW91/DGDZVP2 level. ${ }^{16)}$ As shown in Fig. 6 , the experimental spectrum of $\mathbf{2}$ and the calculated VCD spectrum of the $\mathrm{CHCl}_{3}$ complex of $\mathbf{2}$ were very similar. Thus, tuberostemospiroline (2) was determined to have $9 S, 9 \mathrm{a} S$, and $11 R$ configuration, as shown in Fig. 1.

Stemona-lactam S (1) and tuberostemospiroline (2) are structurally related to stemoninoamide ${ }^{17)}$ and croomine, ${ }^{18)}$ respectively. As the absolute configuration of the chiral centers of alkaloids $\mathbf{1}$ and $\mathbf{2}$ is the same as those of the corresponding carbon atoms of stemoninoamide and croomine, respectively, alkaloids $\mathbf{1}$ and $\mathbf{2}$ are considered to be biogenetically derived from those alkaloids, respectively.

\section{Experimental}

General Melting points were determined on a Yanaco MP-3 apparatus and recorded uncorrected. Optical rotations were measured on a JASCO P-1030 digital polarimeter and IR spectra, on a JASCO FT/IR 620 spectrophotometer. NMR spectra were recorded on a Bruker AV-600 or DRX-500 spectrometer at $300 \mathrm{~K}$. The ${ }^{1} \mathrm{H}$ chemical shifts in $\mathrm{CDCl}_{3}$ and $\mathrm{CD}_{3} \mathrm{OD}$ were each referenced to the residual chloroform $(\delta$ $7.26 \mathrm{ppm})$ or $\mathrm{CD}_{2} \mathrm{HOD}(\delta 3.31 \mathrm{ppm})$ resonance, and the ${ }^{13} \mathrm{C}$ chemical shifts, to the solvent resonance $(\delta 77.03$ or $49.0 \mathrm{ppm})$. Mass spectra were obtained with a Micromass LCT spectrometer. Single crystal X-ray diffraction data were collected using a Bruker SMART APEX II CCD diffractometer equipped with a multilayer confocal mirror and a fine-focus rotating
Table 1. Calculated Relative Energies (kcal/mol) and Populations (\%) of the Three Lowest Energy Conformers of 1

\begin{tabular}{ccc}
\hline \hline Conformer & $\Delta G^{a)}$ & $P(\%)^{b)}$ \\
\hline 1a & 0.00 & 65.4 \\
1b & 0.54 & 26.2 \\
1c & 1.21 & 8.4 \\
\hline
\end{tabular}

a) Calculated relative energies to 1a with $\Delta G=-565057.50 \mathrm{kcal} / \mathrm{mol}$ at the DFT/ B3PW91/DGDZVP2 level. b) Boltzmann population at $T=298 \mathrm{~K}$ and $1 \mathrm{~atm}$.

anode $(\mathrm{MoK} \alpha, \lambda=0.71073 \AA)$ in the phi and omega scan modes at $90 \mathrm{~K}$. Preparative HPLC was carried out using a Shimadzu LC-6AD system equipped with an SPD-10A UV detector $(220 \mathrm{~nm})$ and a reversed phase column, Wakosil-II 5C18HG prep $(5 \mu \mathrm{m}, 20 \times 250 \mathrm{~mm})$, with a $\mathrm{MeOH}-\mathrm{H}_{2} \mathrm{O}$ mixture as the mobile phase, at the flow rate of $10 \mathrm{~mL} / \mathrm{min}$.

Plant Material The procurement and identification of plant material were made as described in the previous paper. ${ }^{5}$

Extraction and Isolation The air-dried roots $(15 \mathrm{~kg})$ were extracted with hot $\mathrm{MeOH}(3 \times 35 \mathrm{~L})$. The solvent was evaporated to give a crude $\mathrm{MeOH}$ extract $(8 \mathrm{~kg})$, which was, after acidification with $3 \%$ aqueous tartaric acid $(8 \mathrm{~L})$, treated with EtOAc $(3 \times 8 \mathrm{~L})$. The combined EtOAc layers were evaporated in vacuo to give a residue (mixture of neutral and acidic components, $300 \mathrm{~g}$ ). The aqueous layer was adjusted to $\mathrm{pH} 9$ with solid $\mathrm{Na}_{2} \mathrm{CO}_{3}$ and extracted with $\mathrm{CHCl}_{3}(3 \times 8 \mathrm{~L})$. The combined $\mathrm{CHCl}_{3}$ extracts were evaporated in vacuo to give a residue (basic fraction, $250 \mathrm{~g}$ ), which was subjected to HP-20 (DIAION, 1250 g) column chromatography eluting with $\mathrm{MeOH}(10 \mathrm{~L})$, and then with acetone $(3 \mathrm{~L})$. The residue from the $\mathrm{MeOH}$ fraction (206g) was placed on an alumina column (Merck Aluminiumoxid 90, 2kg) and eluted sequentially with $\mathrm{CHCl}_{3}$ (4L), $\mathrm{CHCl}_{3}-\mathrm{MeOH}(5: 1,2 \mathrm{~L})$, and $\mathrm{MeOH}$ (2L). The residue from the $\mathrm{CHCl}_{3}$ fraction $(150 \mathrm{~g})$ was placed on a silica gel column (Merck Kieselgel 60, 70-230 mesh, 900g) and eluted with petroleum ether containing an increasing amount of EtOAc $(4: 1$ to $0: 1,22 \mathrm{~L})$, and then with $\mathrm{CHCl}_{3}-\mathrm{MeOH}$ $(10: 1,4.5 \mathrm{~L})$. The $\mathrm{CHCl}_{3}-\mathrm{MeOH}(10: 1)$ fraction $(13.5 \mathrm{~g})$ was further subjected to silica gel column chromatography eluting sequentially with petroleum ether-acetone $(1: 1,4 \mathrm{~L})$, acetone $(1 \mathrm{~L})$, and $\mathrm{MeOH}(1 \mathrm{~L})$ to give four fractions. The third fraction (4.42 g, acetone eluate) gave, by ODS HPLC eluting with $\mathrm{MeOH}-0.1 \mathrm{M}$ aqueous $\mathrm{NH}_{4} \mathrm{OAc}(35: 65)$, stemoninoamide $(2.0 \mathrm{~g})$. This stemoninoamide was not pure and recrystallization from $\mathrm{Et}_{2} \mathrm{O}$-acetone $(1: 1)$ gave stemoninoamide $(1.5 \mathrm{~g})$ and the mother liquor. The mother liquor was concentrated and applied to an ODS HPLC column eluting with $\mathrm{MeOH}-0.1 \mathrm{M}$ aqueous $\mathrm{NH}_{4} \mathrm{OAc}(35: 65)$ to give tuberostemospiroline (2) (30 mg).

The mixture of neutral and acidic components ( $300 \mathrm{~g}$ ) was subjected to silica gel $(1700 \mathrm{~g})$ column chromatography eluting sequentially with hexane-EtOAc $(3: 1,5 \mathrm{~L})$, hexane-EtOAc $(1: 1,5 \mathrm{~L})$, EtOAc (5 L), EtOAc-MeOH $(10: 1,8 \mathrm{~L})$, and $\mathrm{MeOH}$ $(8 \mathrm{~L})$ to afford six fractions. The fourth fraction $(43.6 \mathrm{~g})$, which was a part of the EtOAc-MeOH $(10: 1)$ eluate, was subjected to aminopropyl-bonded silica gel $(570 \mathrm{~g})$ column chromatography eluting sequentially with hexane-EtOAc $(1: 0,3: 1,1: 1$, $1: 3$, and $0: 1,4 \mathrm{~L}$ each), EtOAc-MeOH $(10: 1,8 \mathrm{~L})$, and $\mathrm{MeOH}$ (8L) to give seven fractions (fractions 1-7). After evaporating the solvent to dryness, fraction 4 (hexane-EtOAc $1: 3$ eluate, $0.72 \mathrm{~g})$ was subjected to HPLC using $\mathrm{MeOH}-\mathrm{H}_{2} \mathrm{O}(35: 65$, 
$65: 35$, and $100: 0)$ to afford stemona-lactam $\mathrm{S}$ (1) (13.2 mg). Fraction 5 (EtOAc eluate, $0.33 \mathrm{~g}$ ) was subjected to HPLC using $\mathrm{MeOH}-\mathrm{H}_{2} \mathrm{O}(40: 60$, and $100: 0)$ to afford nine fractions. The fifth fraction $(37.2 \mathrm{mg})$ was subsequently purified by HPLC using $\mathrm{MeOH}-\mathrm{H}_{2} \mathrm{O}(32: 68)$ to give stemona-lactam $\mathrm{S}$ (1) $(5.3 \mathrm{mg})$.

Characteristics of Each Alkaloid Stemona-Lactam S (1): Colorless prisms $\left(\mathrm{MeOH}-\mathrm{H}_{2} \mathrm{O}\right), \mathrm{mp} 196-197^{\circ} \mathrm{C} ;[\alpha]_{\mathrm{D}}^{25}-174$ $(c=0.11, \mathrm{MeOH})$; IR $v_{\max }$ (film): 3379, 2935, 2877, 1760, and $1671 \mathrm{~cm}^{-1}$; ${ }^{1} \mathrm{H}-\mathrm{NMR}\left(600 \mathrm{MHz}, \mathrm{CDCl}_{3}\right.$, major conformer) $\delta$ : $6.71(1 \mathrm{H}, \mathrm{q}, J=1.5 \mathrm{~Hz}, \mathrm{H}-12), 5.95(1 \mathrm{H}, \mathrm{brm}, \mathrm{NH}), 3.94(1 \mathrm{H}$, td, $J=11.0,3.5 \mathrm{~Hz}, \mathrm{H}-8), 3.39(1 \mathrm{H}, \mathrm{m}, \mathrm{H}-5 \mathrm{a}), 3.23(1 \mathrm{H}, \mathrm{m}$, H-5b), 3.06 (1H, t, $J=11.0 \mathrm{~Hz}, \mathrm{H}-9), 2.73$ (1H, ddd, $J=11.0$, 8.1, 5.0 Hz, H-10), $2.32(1 \mathrm{H}, \mathrm{m}, \mathrm{H}-7 \mathrm{a}), 1.94(3 \mathrm{H}, \mathrm{d}, J=1.5 \mathrm{~Hz}$, $\left.\mathrm{H}_{3}-15\right), 1.92(1 \mathrm{H}, \mathrm{m}, \mathrm{H}-6 \mathrm{a}), 1.81(1 \mathrm{H}, \mathrm{qd}, J=13.0,4.0 \mathrm{~Hz}$, $\mathrm{H}-7 \mathrm{~b}), 1.57$ (1H, m, H-16a), 1.56 (1H, m, H-6b), 1.42 (1H, m, $\mathrm{H}-16 \mathrm{~b}), 0.85\left(3 \mathrm{H}, \mathrm{t}, J=7.5 \mathrm{~Hz}, \mathrm{H}_{3}-17\right) ;{ }^{13} \mathrm{C}-\mathrm{NMR}(150 \mathrm{MHz}$, $\mathrm{CDCl}_{3}$, major conformer) $\delta$ : 172.7 (C-9a), 171.5 (C-14), 144.7 (C-12), 133.6 (C-13), 113.2 (C-11), 80.3 (C-8), 52.9 (C-9), 49.0 (C-10), 42.0 (C-5), 35.9 (C-7), 27.2 (C-6), 20.5 (C-16), 12.6 (C-17), 10.6 (C-15); HR-ESI-MS: $m / z \quad 288.1219 \quad[\mathrm{M}+\mathrm{Na}]^{+}$ (Calcd for $\mathrm{C}_{14} \mathrm{H}_{19} \mathrm{NO}_{4} \mathrm{Na}, 288.1212$ ).

Tuberostemospiroline (2): Colorless prisms $\left(\mathrm{MeOH}-\mathrm{H}_{2} \mathrm{O}\right)$, mp $136-137^{\circ} \mathrm{C} ;[\alpha]_{\mathrm{D}}^{25}-34(c=0.07, \mathrm{MeOH}) ; \operatorname{IR} v_{\max }$ (film): 2938, 2877, 1771, and $1680 \mathrm{~cm}^{-1}$; ${ }^{1} \mathrm{H}-\mathrm{NMR}\left(500 \mathrm{MHz}, \mathrm{CD}_{3} \mathrm{OD}\right)$ $\delta: 4.03(1 \mathrm{H}, \mathrm{dd}, J=8.9,7.3 \mathrm{~Hz}, \mathrm{H}-9 \mathrm{a}), 3.65$ (1H, ddd, $J=13.6$, $6.5,2.6 \mathrm{~Hz}, \mathrm{H}-5 \mathrm{a}), 3.21$ (1H, ddd, $J=13.6,10.0,2.0 \mathrm{~Hz}, \mathrm{H}-5 \mathrm{~b})$, $2.86(1 \mathrm{H}, \mathrm{m}, \mathrm{H}-11), 2.53(1 \mathrm{H}, \mathrm{dd}, J=13.6,10.2 \mathrm{~Hz}, \mathrm{H}-10 \mathrm{a})$, 2.44-2.32 (2H, m, H -2$), 2.19$ (1H, m, H-1a), 2.02-1.87 (3H, m, H-7a, H-8a, H-8b), 1.77 (1H, dd, $J=13.6,7.9 \mathrm{~Hz}, \mathrm{H}-10 \mathrm{~b}), 1.73$ (1H, m, H-6a), 1.67 (1H, m, H-1b), 1.63-1.51 (2H, m, H-6b, $\mathrm{H}-7 \mathrm{~b}), 1.30\left(3 \mathrm{H}, \mathrm{d}, J=7.4 \mathrm{~Hz}, \mathrm{H}_{3}-13\right) ;{ }^{13} \mathrm{C}-\mathrm{NMR}(125 \mathrm{MHz}$, $\left.\mathrm{CD}_{3} \mathrm{OD}\right) \delta$ : 181.2 (C-12), 177.5 (C-3), 89.2 (C-9), 67.7 (C-9a), 43.3 (C-5), 38.7 (C-8), 38.5 (C-10), 36.5 (C-11), 30.9 (C-2), 28.6 (C-6), 23.5 (C-7), 23.1 (C-1), 17.4 (C-13); HR-ESI-MS: $m / z$ $238.1443[\mathrm{M}+\mathrm{H}]^{+}$(Calcd for $\left.\mathrm{C}_{13} \mathrm{H}_{20} \mathrm{NO}_{3}, 238.1443\right)$.

X-Ray Crystallographic Study Stemona-Lactam S (1): $\mathrm{C}_{14} \mathrm{H}_{19} \mathrm{NO}_{4}, \quad M=265.30, \quad 0.29 \times 0.24 \times 0.12 \mathrm{~mm}, \quad$ monoclinic, $P 2_{1}, \quad a=7.6013(8) \AA, \quad b=8.9374(10) \AA, \quad c=10.3357(12) \AA, \quad \beta=$ $106.2166(4)^{\circ}, \quad V=674.23 \quad(13) \AA^{3}, \quad Z=2, \quad D_{\text {calc }}=1.307 \mathrm{~g} / \mathrm{cm}^{3}$, $\mu(\mathrm{MoK} \alpha)=0.10 \mathrm{~mm}^{-1}, \quad T=90 \mathrm{~K}, 3250$ measured reflections, 2173 independent reflections $\left(R_{\text {int }}=0.012\right), 2131$ observed reflections with $I>2 \sigma(I), R_{1}=0.0250, w R_{2}=0.0649$ (observed data), $R_{1}=0.0255, w R_{2}=0.0655$ (all data), $S=1.03$, Flack parameter $=0.8(7)$.

Tuberostemospiroline (2): $\mathrm{C}_{13} \mathrm{H}_{19} \mathrm{NO}_{3}, \quad M=237.29, \quad 0.30 \times$ $0.21 \times 0.17 \mathrm{~mm}$, orthorhombic, $P 2_{1} 2_{1} 2_{1}, \quad a=8.4665(9) \AA, \quad b=$ 10.0481(11) $\AA, c=13.7603(15) \AA, V=1170.6(2) \AA^{3}, Z=4, D_{\text {calc }}=$ $1.346 \mathrm{~g} / \mathrm{cm}^{3}, \mu(\mathrm{MoK} \alpha)=0.10 \mathrm{~mm}^{-1}, T=90 \mathrm{~K}, 5643$ measured reflections, 2069 independent reflections $\left(R_{\text {int }}=0.019\right), 2018$ observed reflections with $I>2 \sigma(I), R_{1}=0.0291, w R_{2}=0.0729$ (observed data), $R_{1}=0.0301, w R_{2}=0.0738$ (all data), $S=1.06$, Flack parameter $=-0.1(10)$.

Crystallographic data (excluding structure factors) have been deposited at the Cambridge Crystallographic Data Centre under CCDC deposition numbers (1) CCDC-955473 and (2) CCDC-955472. Copies of the data can be obtained free of charge on application to the CCDC, 12 Union Road, Cambridge CB2 IEZ, U.K. Fax: +44-(0)1223-336033 or e-mail: deposit@ccdc.cam.ac.uk.

IR and VCD Measurements IR and VCD spectra were measured with a Dual-PEM Chiral IR-2X FT-VCD spectrometer (BioTools, Inc., Jupiter, FL, U.S.A.) using a resolution of $4 \mathrm{~cm}^{-1} .3 .6 \mathrm{mg}$ of $\mathbf{1}$ and $3.1 \mathrm{mg}$ of 2 were each dissolved in $150 \mu \mathrm{L}$ of $\mathrm{CDCl}_{3}$ and placed in a $\mathrm{BaF}_{2}$ cell with a path length of $75 \mu \mathrm{m}$. Six data blocks for $2 \mathrm{~h}$ were collected and averaged, and the baseline was corrected by subtracting the spectrum of $\mathrm{CDCl}_{3}$ acquired under the same conditions.

Molecular Modeling and VCD Calculations The conformational analysis of $\mathbf{1}$ and $\mathbf{2}$ was performed by a Monte Carlo search with the MMFF94S force field using MacroModel ver. 7.0 software (Schrödinger Inc., Portland, OR, U.S.A.). Calculations consisted of 50000 steps. Five conformers for $\mathbf{1}$ and four conformers for 2 were found within $5 \mathrm{kcal} / \mathrm{mol}$ from the global minimum conformations, respectively. All the obtained structures were subjected to single point calculations at the DFT/B3LYP/6-31G(d,p) level. The geometric optimization and the calculations of the free energies and the frequencies were performed at the DFT/B3PW91/DGDZVP2 level using Gaussian 09W software (Gaussian, Inc., Wallingford, CT, U.S.A.). ${ }^{19)}$ The calculated IR and VCD spectra were obtained with Lorentzian band shapes of $4 \mathrm{~cm}^{-1}$ half-width at half-height. The frequencies of the calculated spectra were scaled by a factor of 0.98 using CompareVOA software (BioTools, Inc., Jupiter, FL, U.S.A.). ${ }^{20)}$

Acknowledgment This work was supported by a Grantin-Aid for Scientific Research from the Japan Society for the Promotion of Science.

\section{References}

1) Sakata K., Aoki K., Chang C.-F., Sakurai A., Tamura S., Murakoshi S., Agric. Biol. Chem., 42, 457-463 (1978).

2) Brem B., Seger C., Pacher T., Hofer O., Vajrodaya S., Greger H., J. Agric. Food Chem., 50, 6383-6388 (2002).

3) Chung H.-S., Hon P.-M., Lin G., But P. P.-H., Dong H., Planta Med., 69, 914-920 (2003).

4) Hitotsuyanagi Y., Hikita M., Uemura G., Fukaya H., Takeya K., Tetrahedron, 67, 455-461 (2011).

5) Hitotsuyanagi Y., Fukaya H., Takeda E., Matsuda S., Saishu Y., Shu Z., Komatsu K., Takeya K., Tetrahedron, 69, 6297-6304 (2013).

6) Hua J.-P., Yang D.-H., Lin W.-H., Cai S.-Q., Helv. Chim. Acta, 92, 2125-2133 (2009).

7) Bruker Suite, Bruker AXS Inc., Madison, U.S.A., 2008.

8) Sheldrick G. M., SADABS, Bruker AXS area detector scaling and absorption, Version 2008/1, Univ. of Göttingen, 2008.

9) Sheldrick G. M., SHELXS-97, Program for crystal structure solution of crystal structures, Univ. of Göttingen, 1997.

10) Sheldrick G. M., SHELXL-97, Program for crystal structure refinement of crystal structures, Univ. of Göttingen, 1997.

11) Flack H. D., Acta Crystallogr. A, 39, 876-881 (1983).

12) Aoyagi Y., Yamazaki A., Kato R., Tobe F., Fukaya H., Nishikawa T., Nakahashi A., Miura N., Monde K., Takeya K., Tetrahedron Lett., 52, 1851-1853 (2011).

13) Manríquez-Torres J. J., Torres-Valencia J. M., Gómez-Hurtado M. A., Motilva V., García-Mauriño S., Avila J., Talero E., CerdaGarcía-Rojas M. C., Joseph-Nathan P., J. Nat. Prod., 74, 1946-1951 (2011).

14) Felippe L. G., Batista J. M. Jr., Baldoqui D. C., Nascimento I. R., Kato M. J., He Y., Furlan M., Org. Biomol. Chem., 10, 4208-4214 (2012).

15) Freedman T. B., Cao X., Dukor R. K., Nafie L. A., Chirality, 15, 743-758 (2003).

16) Nafie L. A., "Vibrational Optical Activity: Principles and Applica- 
tions," John Wiley \& Sons, Chichester, 2011, pp. 275-276.

17) Kakuta D., Hitotsuyanagi Y., Matsuura N., Fukaya H., Takeya K., Tetrahedron, 59, 7779-7786 (2003).

18) Noro T., Fukushima S., Ueno A., Miyase T., Iitaka Y., Saiki Y., Chem. Pharm. Bull., 27, 1495-1497 (1979).

19) Frisch M. J., Trucks G. W., Schlegel H. B., Scuseria G. E., Robb M. A., Cheeseman J. R., Scalmani G., Barone V., Mennucci B., Petersson G. A., Nakatsuji H., Caricato M., Li X., Hratchian H. P., Izmaylov A. F., Bloino J., Zheng G., Sonnenberg J. L., Hada M., Ehara M., Toyota K., Fukuda R., Hasegawa J., Ishida M., Nakajima T., Honda Y., Kitao O., Nakai H., Vreven T., Montgomery J. A. Jr., Peralta J. E., Ogliaro F., Bearpark M., Heyd J. J., Brothers E., Kudin
K. N., Staroverov V. N., Kobayashi R., Normand J., Raghavachari K., Rendell A., Burant J. C., Iyengar S. S., Tomasi J., Cossi M., Rega N., Millam J. M., Klene M., Knox J. E., Cross J. B., Bakken V., Adamo C., Jaramillo J., Gomperts R., Stratmann R. E., Yazyev O., Austin A. J., Cammi R., Pomelli C., Ochterski J. W., Martin R. L., Morokuma K., Zakrzewski V. G., Voth G. A., Salvador P., Dannenberg J. J., Dapprich S., Daniels A. D., Farkas O., Foresman J. B., Ortiz J. V., Cioslowski J., Fox D. J., "GAUSSIAN 09W" Revision B. 01, Gaussian Inc., Wallingford CT, 2010.

20) Debie E., De Gussem E., Dukor R. K., Herrebout W., Nafie L. A., Bultinck P., ChemPhysChem, 12, 1542-1549 (2011). 